\title{
SIGMUND E CLARICE: UM DIÁLOGO SINGULAR SOBRE DESEJO ${ }^{1}$
}

\author{
Santo Gabriel Vaccaro ${ }^{2}$
}

\begin{abstract}
Quando passava pelo Picadilly Circle e via as mulheres esperando homens nas esquinas, só faltava vomitar. Ainda mais por dinheiro! Era demais para se suportar. E aquela estátua de Eros, ali, indecente.

"Miss Algrave". Lispector, 1998b.
\end{abstract}

Escrevo sobre o mínimo parco enfeitando-o com púrpura, jóias e esplendor. É assim que se escreve? Não, não é acumulando e sim desnudando. Mas tenho medo da nudez, pois ela é a palavra final. A bora da estrela. Lispector, 1998a.

Um relato que aborde erotismo, sonho ou desejos humanos propicia uma oportunidade singular de traçar paralelas entre campos a priori distantes como a psicanálise e a literatura, e essas relações tecidas entre ambos, essas sendas entre aparentes extremos, unem o que está em princípio discriminado ou desprendido. Essa é a sensação que resulta de vincular a teoria psicanalítica de Sigmund Freud ao texto literário no caso e Clarice Lispector, uma sensação que carrega uma ideia de aproximação, de redução ou de encurtamento. Tanto na escrita de Freud como na de Lispector é possível levar uma teoria ou prática terapêutica ao texto de ficção ou levar este último até aquela.

Mas também, em alguns textos dos autores citados, a impressão de ligar o afastado, de unir os extremos parece ganhar uma força especial chegando-se à impossibilidade de conceber uma divisão entre campos, uma separação entre alas, um sulco entre setores. Este é o caso de alguns relatos de Clarice Lispector que abordam temáticas oníricas ou eróticas, como "Onde estivestes de noite" ou "Ms. Algrave" e de textos como "El delirio y los sueños en la 'Gradiva' de W. Jensen”' de Freud, onde a personagem principal da narração é sujeito da prática psicanalítica. Textos em que, devido à presença tão marcada do

\footnotetext{
${ }^{1}$ Este artigo é o resultado das leituras e discussões desenvolvidas no curso "Literatura, Psicanálise, Cinema: o gesto como meio", ministrado pela Profa. Dra. Ana Luiza de Andrade no primeiro semestre de 2010 na PósGraduação em Literatura da Universidade Federal de Santa Catarina.

2 Doutorando da Pós-Graduação em Literatura da Universidade Federal de Santa Catarina - UFSC e professor de Literatura Hispânica da Universidade Federal da Fronteira Sul - UFFS. Membro do Núcleo Juan Carlos Onetti de Estudos Literários Latino-Americanos da UFSC e do Grupo de Estudos Trânsitos Literários da UFFS.
} 
pensamento psicanalítico, as fronteiras entre este último e a literatura sucumbem para estabelecer uma espécie de fusão ou mistura do divorciado.

A hora da estrela, pelas especiais circunstâncias que rodeiam sua protagonista, a jovem nordestina Macabéa, e pelos singulares traços que o narrador, Rodrigo S. M., atribui a ela, também pode ser considerado um desses textos onde as fronteiras entre literatura e psicanálise atenuam seus contornos.

A vinculação existente entre a psicanálise e a literatura nos textos acima referidos repousa, de certa forma, num patamar construído com a junção dos elementos que sustentam tanto a teoria psicanalítica como a literatura, a reflexão teórica e a imaginação.

Assim, em certos textos freudianos ou clariceanos o pensamento rigoroso vem associar-se à criação artística despontando, de certa forma, uma espécie de comunhão entre o método científico e a ficção.

E é precisamente o homem, e especialmente aqui o homem que escreve ou que narra, o elemento que permite a convergência das esferas afastadas, a concordância das jurisdições distanciadas. O homem como trajeto unificador, como passagem harmônica, como construtor de alianças. Aliança, neste trabalho, de um psicanalista e uma escritora que dialogam no mesmo espaço e no mesmo tempo, aliás, na mesma hora, hora de uma estrela nordestina que em cada frase de Rodrigo S. M., quem a conta e modela, abre uma porta a uma leitura que vai muito além da literatura.

\section{Laços e relações: psicanálise e literatura}

Psicanalista ou escritor, sujeito ou objeto das próprias criações, elaborador de uma teoria ou construtor de uma ficção, o homem é, em definitiva, o ponto de enlace mais forte entre as diversas disciplinas que surgem de suas reflexões e de seu imaginário. Por isso, dos variados pontos de enlace que entre psicanálise ${ }^{3}$ e literatura podem ser traçados, os

\footnotetext{
3 Seguindo os preceitos de Laplanche e Pontalis, a psicanálise deve ser entendida, além de uma disciplina fundada por Sigmund Freud, como um método de investigação, como um método psicoterápico e como um conjunto de teorias psicológicas e psicopatológicas. Quando se faz referência ao método de investigação, deve ser considerado que este se baseia em associações livres dos sujeitos e que busca, basicamente, evidenciar a significação inconsciente das palavras, dos atos e das produções imaginárias como sonhos, fantasias ou delírios das pessoas. Como método psicoterápico, a psicanálise está baseada na investigação controlada da resistência da transferência e do desejo. Já como conjunto de teorias psicológicas e psicopatológicas, deve-se ter presente que nestas teorias são sistematizados os dados que surgem da aplicação do método psicanalítico de investigação e tratamento (LAPLANCHE, Jean; PONTALIS, Jean-Bertrand. Diccionario de Psicoanálisis. Buenos Aires: Paidós, 2001, p.316).
} 
conflitos e as preocupações do homem sobressaem ${ }^{4}$. Claro que o ser humano não só resulta ser o nexo ou o vínculo entre as disciplinas referidas, ele é a mesma fonte ou causa da existência da psicanálise e da literatura. Neste mesmo sentido, Willemart afirma que "ambas as práticas literárias e psicanalítica derivam do mesmo homem preocupado com seu passado, a tradição, a cultura e o futuro" ${ }^{5}$. Uma apreciação de tal índole, embora muito geral, exibe um primeiro ponto de contato entre a literatura e a psicanálise que, de certa forma, aproximaria as preocupações científicas freudianas e as que, na ficção, Rodrigo S. M. atribui a Macabéa.

E como o homem é um ponto de contato e também uma causa de vinculação entre psicanálise e literatura, o psicanalista ${ }^{6}$ e o escritor podem ser pensados como os artífices, com seus como e seus de que forma abordar esta relação, da ligação entre a ciência freudiana e a ficção clariceana.

Uma destas possibilidades de aproximação entre disciplinas se observa nos casos em que a literatura parece ir ao encontro da psicanálise. Neste sentido, a forma do relato, o como ele é produzido permite que a narração psicanalítica se aproxime à literária.

O estilo, o uso especial da linguagem utilizada no texto e a vontade estética de quem escreve deixam perceber um verdadeiro uso literário da linguagem.

Um bom exemplo de um uso literário da linguagem em um texto científico freudiano pode ser identificado na descrição de um sonho em El miramiento por la figurabilidad:

Ella se encuentra en el teatro. Representan una obra de Wagner. La función ha durado hasta las 7 y cuarto de la mañana. En la platea y los palcos bajos hay mesas donde se come y se bebe. Su primo, que acaba de volver a casa tras su viaje de bodas, está sentado a una de estas con su joven esposa; junto a ellos un aristócrata. De este se dice que la joven se lo trajo de su viaje de bodas desenbozadamente como habría podido hacerlo con un sombrero ${ }^{7}$.

\footnotetext{
4 A respeito dos questionamentos humanos sobre sua existência, Bellemin-Noël assinala que "é só com alguma coisa como literatura [...] que o homem se interroga sobre si mesmo, sobre seu destino cósmico, sua história, seu funcionamento social e mental" (BELLEMIN-NOËL, Jean. Psicanálise e literatura. São Paulo: Cultrix, 1978, p.12).

5 WILLEMART, Philippe. Além da psicanálise: a literatura e as artes. São Paulo: Nova Alexandria: FAPESP, 1995, p.154.

${ }^{6}$ Moritz-Kon vai além desta ideia de pensar Freud como um construtor de uma relação entre psicanálise e literatura e postula a utilização desta última como uma espécie de base onde apoiar seu edifício conceitual psicanalítico. Assim, Moritz-Kon refere: "As relações da psicanálise com a arte -e com a literatura, em especial- são inequívocas e têm sido uma constante desde os primeiros passos das formulações freudianas. Surgem, inicialmente, como impulso para a consecução e positivação dos conceitos fundadores da disciplina psicanalítica, como o complexo de Édipo e a noção de inconsciente. Nestes primórdios da construção da teoria freudiana, a obra de arte comparece para afiançar as hipóteses originais criadas, com o propósito de garantir a universalidade necessária para os conceitos que o psicanalista vienense postula a partir de seu processo de auto-análise" (MORITZ-KON, Noemí. "De Poe a Freud - O gato preto". In: BARTUCCI, Giovanna (Org.). Psicanálise, literatura e estéticas de subjetivação. Rio de Janeiro: Imago, 2001, p.91).

${ }^{7}$ FREUD, Sigmund. Obras Completas. v. V. Buenos Aires: Amorrortu, 2000, p.348.
} 
Note-se que na descrição freudiana a linguagem utilizada parece apartar-se voluntariamente da linguagem corrente com o objetivo de embelezar a expressão e desta forma causar no leitor certa atração, não só pelo dito, mas também pela forma de dizê-lo.

Em El miramiento por la figurabilidad, o sonho é descrito por Freud com uma singular elegância estética que possibilita, em um primeiro momento, entender que existe o propósito de descrever um sonho com uma finalidade científica ou pedagógica, mas também deixa entrever na sua refinada narração uma evidente carga estética.

Carga que, além da cuidada prosa de sua descrição psicanalítica, exibe a inclinação e a admiração freudiana pela literatura e pelos poetas, entendidos estes últimos em um sentido amplo que abarca, segundo Willemart, tanto a romancistas como a dramaturgos ${ }^{8}$.

Mas assim como a literatura descansa numa descrição freudiana de um sonho, pode acontecer que a prática psicanalítica se intrometa no texto literário ${ }^{9}$. Exemplos deste último caso se observam com clareza, por exemplo, na análise que Freud faz da Gradiva de Jensen.

Nesta análise freudiana se observa o emprego de um texto literário no interesse da psicanálise e se percebe como Freud chega até a literatura com seu edifício teórico para escrever um novo texto que utiliza o campo literário para fortalecer os princípios da psicanálise. Em El delírio y los sueños en la "Gradiva" de W. Jensen, ao aplicar seu método ao protagonista do romance, o arqueólogo Norbert Hanold, Freud permite presumir que se a psicanálise pode interpretar ou elucidar o que narra ou o que sonha um homem/paciente, também poderá decifrar as falas ou os sonhos de um narrador ou de um personagem de um texto de ficção.

E é neste último sentido, o do interpretar com algumas noções da teoria freudiana o dito por um narrador ou por um personagem, é que se tenta uma aproximação entre a psicanálise e a textualidade clariceana em $A$ bora da estrela.

\footnotetext{
8 WILLEMART, Philippe. Além da psicanálise: a literatura e as artes. São Paulo: Nova Alexandria: FAPESP, 1995, p.79. Também Bellemin-Noël, referindo esta particular inclinação freudiana às letras, assinala que o psicanalista súço escreveu tanto sobre artistas, como sobre escritores, fenômenos literários e obras particulares, e destaca como os mais importantes livros que abordaram tais questões os seguintes: em 1907, Delírios e sonhos na "Gradiva" de Jensen (Vol. IX); em 1908, Escritores Criativos e Devaneio, (Vol. IX); em 1910, Leonardo da Vinci e uma Recordação da sua Infância, (Vol. XI); em 1913, O Tema dos Três Escrutínios, (Vol. XIII); em 1914, O Moisés de Michelangelo, (Vol. XIII); em 1916, Alguns Tipos Característicos Encontrados no Trabalho Psicanalitico, (Vol. XIV); em 1917, Uma Lembrança de Infância "Dichtung und Wabrbeit", (Vol. XVII); em 1919, O Sobrenatural, Parte 1, (Vol. XVII); e em 1928, Dostoievsky e o Parricídio, (Vol. XXI) (BELLEMIN-NOËL, Jean. Psicanálise e literatura. São Paulo: Cultrix, 1978, p.21).

9 Entre esta utilização de uma linguagem literária no texto psicanalítico, ou esta aproximação da teoria freudiana ao texto literário, existem outras possibilidades como, por exemplo, a que surge de pensar a literatura sob os princípios da psicanálise, como no caso do trabalho El creador literario y el fantaseo de 1908. Neste texto, Freud reflete acerca da atividade de criação dos poetas, do acesso destes às emoções dos leitores e das fontes que os escritores utilizam para dar vida a suas criações. Assim, por exemplo, Freud pergunta: “¿Estamos realmente autorizados a comparar al poeta con el 'soñante a pleno día', y a sus creaciones con unos sueños diurnos?” (FREUD, Sigmund. Obras Completas. v. IX. Buenos Aires: Amorrortu, 1996, p.131).
} 
Em Clarice Lispector também pode-se ler essa outra forma de aproximação de disciplinas que se observa quando se realiza uma interpretação analítica de um texto literário, ou seja, quando se parte da psicanálise para chegar à literatura.

E não só Macabéa permite esse tipo de leitura. Também um estudo de tal natureza pode ser efetuado, por exemplo, abordando as fobias, os transtornos de pânico ou os delírios persecutórios de Psiu, singular personagem clariceano que, pelas noites, era presa pelo terror que lhe inspiravam homens, animais e até sua própria imagem. Assim, em "Onde estivestes de noite", observa-se o sofrimento da Psiu quando a narradora explica que aquela tinha pendurado na parede "um quadro que era o de um homem que a fixava bem nos olhos, vigiando-a. Essa figura ela imaginava que a seguia por todos os cantos da casa" ${ }^{\prime 10}$.

Norbert Hanold em Freud ou Psiu em Clarice são exemplos de uma possível leitura que partindo da psicanálise trabalha com o texto literário. Macabéa, a datilógrafa virgem que veio do nordeste, a frágil moça que só comia cachorro quente, quiçá também o seja.

\section{As cinco lições freudianas e uma possível relação.}

Para uma possível relação entre $A$ hora da estrela e a disciplina psicanalítica, vários textos freudianos poderiam ser utilizados. Mas parece mais adequado a um estudo que pretende colocar a ênfase na literatura, abordar tal tarefa com um trabalho da área da psicanálise que possua a menor complexidade possível e que possa ser aplicável ao texto literário sem incursionar em tecnicismos ou teorias de difícil compreensão. E é nesse sentido que será utilizado o texto "Cinco lições de psicanálise", pois o mesmo é definido na sua nota introdutória por James Strachey ${ }^{11}$ como um dos textos freudianos mais simples de serem compreendidos por um público-alvo não especializado. Assim, Strachey afirma que o texto em questão "debe considerarse uno de los más sencillos, en especial si se lo compara con la importante serie de Conferencias de introducción al psicoanálisis que pronunció años más tarde (1916-1917)"12.

\footnotetext{
${ }^{10}$ LISPECTOR, Clarice. Onde estivestes de noite. Rio de Janeiro: Rocco, 1999b, p.50.

11 Strachey (Apud FREUD, Sigmund. Obras Completas. v. XI. Buenos Aires: Amorrortu, 2003, p.5) também afirma sobre as "Cinco lições de psicanálise" que as mesmas, embora vários pontos sobre a teoria psicanalítica tenham sido aprofundados, as conferências (lições) continuam proporcionando um admirável esquema preliminar, que exige pouquíssimas alterações.

12 Apud FREUD, Sigmund. Obras Completas. v. XI. Buenos Aires: Amorrortu, 2003, p.4-5.
} 
Basicamente, as "Cinco lições de psicanálise" são o resultado de uma série de conferências que, em setembro de 1909, Freud ministrou na Clark University de Worcester (Massachusetts), com motivo do $20^{\circ}$ aniversário da fundação de dita instituição. Nestas cinco conferências, o pai da psicanálise aborda temáticas como a histeria e os métodos hipnóticos do doutor Breuer; o método catártico e sua passagem à psicanálise, o abandono da hipnose pela utilização da associação livre e a interpretação dessas associações e dos sonhos; os neuróticos, a sexualidade e o complexo de Édipo; as causa e consequências dos traumas e transtornos e suas possíveis curas.

Todas estas questões derivadas do âmbito psicanalítico dão subsídios, no presente trabalho, para entender melhor as relações tecidas no diálogo proposto entre o mundo da ficção da Clarice Lispector e o campo científico de Sigmund Freud.

E esse mundo ficcional que se assinala e que se quer vincular com as "Cinco lições de psicanálise" repousa em A hora da estrela, livro escrito por Clarice Lispector em 1977.

Em $A$ hora da estrela, contam-se, entre outras coisas (o como narrar; a flexibilização das fronteiras existentes entre autor, narrador, personagem e leitor no texto clariceano; a limitação na escrita causada pela insuficiência e ambiguidade da linguagem etc.) as vicissitudes da existência de uma jovem nordestina, Macabéa, que tenta ter uma vida como datilógrafa numa grande capital brasileira, Rio de Janeiro.

Uma moça que chega até nós conformada por traços que Rodrigo, o narrador clariceano, vai deixando entrever nas suas intermináveis reflexões sobre a voz, sobre a escrita, enfim, sobre a palavra que vai modelando uma história e uma Macabéa. Porque o direito ao grito, Rodrigo o usa, e seu grito é puro e feito de palavras, material básico que se agrupa e forma frases e as mesmas se perdem para sempre num sentido secreto que as ultrapassa $^{13}$. Rodrigo adverte sobre esta rua sem saída. Pode-se gritar, falando ou escrevendo, mas o grito sempre é alguma outra coisa e nunca um grito nosso. É algo que foge de nós depois do primeiro alento, após o sopro, ainda que possamos ter, como Macabéa, uma vida mudada por palavras.

Por isso, trabalhar Macabéa é esculpir algo novo com o mesmo material que Rodrigo trabalhou, a palavra, mas longe se está de chegar perto da jovem nordestina de dezenove anos. Conhecendo essa sombra da linguagem ${ }^{14}$, essa mudez, esse silêncio, Rodrigo

\footnotetext{
${ }^{13}$ LISPECTOR, Clarice. $A$ hora da estrela. Rio de Janeiro: Rocco, 1998a, p.14. Em "Devaneio e embriaguez duma rapariga" também as palavras agrupadas perdem seu significado e alcançam outro patamar de sentidos que poucos podem entender: "Ai, palavras, palavras, objetos do quarto em ordem de palavras, a formarem aquelas frases turvas e maçantes que quem súber ler, lerá" (LISPECTOR, Clarice. Laços de família. Rio de Janeiro: Rocco, 2009, p.16-17).

${ }^{14}$ Em "Os obedientes" observam-se reflexões que redundam nessa mesma ideia de linguagem como ausência de transparência, de linguagem como matéria opaca: "E nesse fundo branco meus olhos se fixariam já tendo
} 
comunica que se limita só "a contar as fracas aventuras de uma moça numa cidade toda feita contra ela" 15 .

Com essas fracas histórias, deve-se duvidar da personagem que o narrador elabora e pensar quem é, então, essa Macabéa que Rodrigo promete. Essa Macabéa poderá ser, em termos clariceanos, uma grande palavra, poderá ser como um reivindicar o direito ao grito, poderá ser, em última instância, uma possibilidade de mitigar a existência do medo ao nome das coisas, pois Macabéa, entre todas as descrições de Rodrigo, é, por um lado, uma vocezinha que tem medo de palavras, mas também, por outro, um singular personagem que aplacava sua fome mastigando, bem mastigadinho, e engolindo papel/palavras.

Mas a protagonista de $A$ bora da estrela também é uma jovem enferrujada, cariada, apagada, morna, quase morta, quiçá o resultado de uma chama atenuada na sua infância difícil no nordeste ${ }^{16}$. Lá, onde uma tia castradora não duvidava um instante ao momento de repreender as condutas da pequena Macabéa com golpes, proibições ou atos quase sádicos.

Sobre este particular, Winter e Motta observam no texto clariceano referências fortes não só ao sadismo, mas também ao sadomasoquismo. A respeito, os autores assinalam que: "Nas práticas eróticas, o sujeito que tem prazer com a dor de outrem é nomeado sádico, enquanto que o sujeito que se faz objeto de si mesmo, tendo prazer com sua própria dor, é chamado masoquista" ${ }^{17}$. Esse sadismo e esse masoquismo, são individualizados pelos autores, não no caso da relação da Macabéa e sua tia, mas na conduta do Rodrigo S(ado). $\mathrm{M}$ (asoquismo), narrador que faz sofrer a sua criação (postura sádica dada pelo prazer da dor dos outros) e que sofre por ela (postura masoquista dada por ocasionar o próprio sofrimento). Em $A$ hora da estrela, na visão dos autores, existe uma interessante vinculação entre a relação sujeito/objeto no plano ficcional e a relação sujeito/objeto no campo do erotismo, ambos extremos unidos por um elemento comum, a tensão entre dor e prazer ${ }^{18}$.

Relação que facilmente pode ser identificada em algumas passagens da descrição do passado de Macabéa sob os cuidados da tia beata em Maceió. A dor e o prazer parecem estar muito presentes nos tempos pretéritos da educação da nordestina. Basta lembrar as histórias de vampiros e de sangue contadas para assustar a pequena Macabéa, ou as

\footnotetext{
bastante o que ver, pois toda palavra tem a sua sombra" (LISPECTOR, Clarice. A legião estrangeira. Rio de Janeiro: Rocco, 1999, p.80-81).

${ }^{15}$ LISPECTOR, Clarice. A hora da estrela. Rio de Janeiro: Rocco, 1998a, p.15.

${ }^{16}$ Gotlib assinala que "como nordestina migrante e pobre, [Macabéa] representa a figura do brasileiro típico, população que vive, na sua maior parte, em condições de extrema miserabilidade" (GOTLIB, Nadia B. Clarice: Uma vida que se conta. São Paulo: Ática, 1995, p.466).

17 WINTER, Lígia Maria; MOTTA, Sérgio Vicente. "O entrecruzamento erótico, pictórico e musical em $A$ hora da estrela”. In: Estudos Linguïsticos, v. XXXV, 2006, p.1124.

${ }^{18} \mathrm{Idem}$.
} 
descrições que o narrador coloca sobre a forma dos castigos e a sensações que eles causavam em quem os aplicava:

[...] a tia lhe dando cascudos no alto da cabeça porque o cocuruto de cabeça devia ser, imaginava a tia, um ponto vital. Dava-lhe sempre com os nós dos dedos na cabeça de ossos fracos por falta de cálcio. Batia mas não era somente porque ao bater gozava de grande prazer sensual - a tia que não se casara por nojo - é que também considerava de dever seu evitar que a menina viesse um dia a ser uma dessas moças que em Maceió ficavam nas ruas de cigarro aceso esperando homem ${ }^{19}$.

Outros castigos que sem agressão física eram tão ou mais dolorosos que os cascudos da tia também são referidos pelo narrador:

\begin{abstract}
As pancadas ela esquecia pois esperando-se um pouco a dor termina por passar. Mas o que doía mais era ser privada da sobremesa de todos os dias: goiabada com queijo, a única paixão na sua vida. Pois não era que esse castigo se tornara o predileto da tia sabida? A menina não perguntava por que era sempre castigada mas nem tudo se precisa saber e não saber fazia parte importante de sua vida ${ }^{20}$.
\end{abstract}

Na singular educação que Macabéa recebe se misturam o sadismo da tutora, o prazer que lhe causava castigar a menina, o medo de um futuro de cigarros e homens, o pavor dos vícios da rua e o receio de uma vida em desacordo à beatitude que moldurava o tipo de ensino praticado.

Assim, por um lado, a religiosidade que se pretende inculcar e, por outro, os atos que originam prazer nas práticas desenvolvidas na educação que a tia carola dá a Macabéa, convivem e perdem seu caráter de elementos a priori contrários ${ }^{21}$ e se erigem como a base de uma instrução que pretende estar mais perto do adestramento que de uma educação familiar. Adestrar para não sentir, para adormecer o erotismo, para anestesiar os impulsos

${ }^{19}$ LISPECTOR, Clarice. A bora da estrela. Rio de Janeiro: Rocco, 1998a, p.28.

${ }^{20}$ Idem.

21 A religiosidade e o erotismo como opostos que perdem suas fronteiras e se misturam, não são exclusividade da Macabéa em A hora da estrela. Madama Carlota, a cartomante do relato, é outro exemplo da convivência pacífica do erótico e da fé católica. Neste sentido, a particular personagem clareciana refere: "Eu sou fã de Jesus. Sou doidinha por Ele. Ele sempre me ajudou. Olha, quando eu era mais moça tinha bastante categoria para levar vida fácil de mulher. E era fácil mesmo, graças a Deus. Depois, quando eu já não valia muito no mercado, Jesus sem mais nem menos arranjou um jeito de eu fazer sociedade com uma coleguinha e abrimos uma casa de mulheres. Aí eu ganhei dinheiro e pude comprar este apartamentozinho térreo" (LISPECTOR, Clarice. A bora da estrela. Rio de Janeiro: Rocco, 1998a, p.73). Também nestes comentários da cartomante, encontram-se restos dessa sociedade conformada pela religiosidade e o erotismo: "Ouvi dizer que o Mangue tem um cheiro insuportável. No meu tempo a gente punha incenso queimando para dar um ar limpo na casa. Até tinha cheiro de igreja. E tudo era muito respeitoso e com muita religião. Quando eu era mulher-dama já ia juntando meu dinheirinho, dando porcentagem à chefa, é claro" (LISPECTOR, Clarice. $A$ hora da estrela. Rio de Janeiro: Rocco, 1998a, p.75). 
sexuais. Um domesticar da tia devota da Macabéa que não impedem suas próprias sensações (e seguramente suas culpas) sádicas e que também não funcionarão na tentativa de amestrar a sexualidade da pequena sobrinha. Os cascudos, os sofrimentos ligados às proibições ou interdições, o vedar as ações que a menina desejava, o acionar ligado a um forte componente religioso, enfim, a educação extremamente castradora não atinge o alvo perseguido pela violência da educação brindada pela tutora. Interditar, disciplinar ou agir violentamente impedem que a pupila seja mulher de rua, "dessas moças que ficavam nas ruas esperando homem", mas não impedem o desenvolvimento das sensações físicas ligadas à sexualidade ${ }^{22}$. Se por um lado, Macabéa é uma moça que nunca se viu nua porque tinha vergonha, pelo outro, ela sabia o que era o desejo - embora não soubesse que sabia.

E esta educação punitiva, impositiva e repressora que se baseia no grande patamar da culpa, atinge, de certa forma, a espiritualidade da Macabéa, mas fazendo nascer nela uma especial religiosidade que chamativamente carece desse Deus inculcado pela tia ${ }^{23}$, uma crença especial em que um pai ocasiona vergonha e culpa, mas estando insolitamente ausente pela apatia da sua filha. Macabéa, a que "rezava indiferentemente", a que carregava o desinteresse pela causa de suas culpas, "não pensava em Deus, Deus não pensava nela. Deus é de quem conseguir pegá-lo" 24 .

A religiosidade da personagem clariceana é um ato sem pensamento, é por momentos a continuidade de sua educação na veneração extrema à ordem, à norma, sem uma reflexão sobre o que se está venerando, o que se está obedecendo em silêncio ${ }^{25}$ e sem meditar. Sobre este particular, o narrador clariceano conta que Macabéa escutou: ““Arrepende-te em Cristo e Ele te dará felicidade’. Então ela se arrependera. Como não

22 Quiçá esta educação que tão rigidamente coloca em extremos opostos os desejos e as práticas religiosas, o que o corpo pede e o que está vedado, e que não prosperou, expliquem de certa forma essa sensação benigna que lhe ocasionava um ato que portasse a ideia de estar pecando. Talvez por essa convivência do permitido e do proibido, Macabéa "arrumara um jeito de achar nas coisas simples e honestas a graça de um pecado" (LISPECTOR, Clarice. A hora da estrela. Rio de Janeiro: Rocco, 1998a, p.63); talvez porque seu Deus (que era, mas não estava presente na sua vida), em ocasiões e num mesmo momento, lhe permitia satisfações e culpas efêmeras: "Mas o misterioso Deus dos outros lhe dava às vezes um estado de graça. [...] Às vezes a graça a pegava em pleno escritório. Então ela ia ao banheiro para ficar sozinha. De pé e sorrindo até passar (pareceme que esse Deus era muito misericordioso com ela: dava-lhe o que lhe tirava)" (LISPECTOR, Clarice. $A$ hora da estrela. Rio de Janeiro: Rocco, 1998a, p.63).

23 Macabéa, dentro de sua indiferença pelo Deus católico, não se sentia totalmente desamparada e pedia desculpas a um ente divino quando o considerava pertinente: "Macabéa, enquanto Glória saía da sala roubou escondido um biscoito. Depois pediu perdão ao Ser abstrato que dava e tirava. Sentiu-se perdoada. $\mathrm{O}$ Ser a perdoava de tudo" (LISPECTOR, Clarice. A hora da estrela. Rio de Janeiro: Rocco, 1998a, p.66).

${ }^{24}$ LISPECTOR, Clarice. A hora da estrela. Rio de Janeiro: Rocco, 1998a, p.26.

25 A ideia de uma atitude silenciosa do homem ante seu Deus também é explícita em Rodrigo, o narrador clariceano: "Se um dia Deus vier à terra haverá silêncio grande" (LISPECTOR, Clarice. A hora da estrela. Rio de Janeiro: Rocco, 1998a, p.86). Mas esta noção de silêncio humano parece ser potencializada no narrador, se comparada com Macabéa, pois o silêncio em Rodrigo vai além do vínculo Deus-homem e chega até, por exemplo, a impossibilidade de dizer existente nas relações tecidas entre um narrador e quem o lê: "Juro que este livro é feito sem palavras. É uma fotografia muda. Este livro é um silêncio" (LISPECTOR, Clarice. $A$ hora da estrela. Rio de Janeiro: Rocco, 1998a, p.16-17). 
sabia bem de quê, arrependia-se toda e de tudo. O pastor também falava que vingança é coisa infernal. Então ela não se vingava" ${ }^{26}$.

Esse arrepender-se de tudo sem pensar, essa assimilação sem censura das diretivas alheias que já não chegavam da tia, mas que continuam sendo obedecidas, essa inércia da Macabéa na sua existência cristã, teve um paralelo na sua sexualidade. Os desejos da Macabéa existiam na ignorância, o prazer se manifestava, mas não era identificável como tal, as condutas pecaminosas não condenavam, pois tudo era rapidamente perdoado, as resistências eram fracas e frágeis em Macabéa e estas não evitavam sua entrega a esses atos queridos, mas resistidos.

O erotismo, a religiosidade, o desejado, o evitado, tudo girava ao redor da Macabéa, mas ela não o percebia, não alcançava a compreender o que acontecia com sua existência cheia de ausências muito presentes. Esta é a razão pela qual a nordestina sabia o que era o desejo, ou pela qual ela se arrependera e como não sabia bem de quê, arrependia-se toda e de tudo.

Mas estas ignorâncias, estes desconhecimentos, este analfabetismo da própria vida da Macabéa não passam em branco para o narrador clariceano. Rodrigo, em dois fragmentos chaves de seu relato, exibe os grandes motivos que dão uma vida intensa e enfática a uma nordestina que parecia quase sem vida ${ }^{27}$, amarelada, cariada: a lascívia, o desejo, a sensualidade. Assim, apresentada como uma infelicidade, Rodrigo refere o forte caráter sensual da jovem nordestina:

\footnotetext{
Macabéa, esqueci de dizer tinha uma infelicidade: era sensual. Como é que num corpo cariado como o dela cabia tanta lascívia, sem que ela soubesse que tinha? Mistério. Havia, no começo do namoro, pedido a Olímpico um retratinho tamanho $3 \times 4$ onde ele saiu rindo para mostrar o canino de ouro e ela ficava tão excitada que rezava três pai-nossos e duas ave-marias para se acalmar ${ }^{28}$.
}

Note-se que, neste fragmento, a Macabéa apresenta-se como um sujeito de enorme complexidade que longe está de uma enxuta e despercebida moça migrante do nordeste. A personagem clariceana, sem sabê-lo, é uma fonte singular de erotismo que tenta reprimir seus desejos rezando automaticamente a um pai ignorado, a um progenitor ausente que desconhecia. Nesse fragmento de $A$ hora da estrela já se observa com estranhamento que a protagonista não é uma jovem a mais apagada entre muitas que procuram uma vida melhor numa grande capital. Macabéa é um grande tecido de sensações que se misturam e perdem

${ }^{26}$ LISPECTOR, Clarice. A hora da estrela. Rio de Janeiro: Rocco, 1998a, p.37.

27 Segundo Barbosa a nordestina "representa uma ausência, um significado vazio: de acordo com a visão do narrador, ela não tem valores nem habilidades que a façam socialmente aceitável e fisicamente desejável" (BARBOSA, Maria José S. Clarice Lispector. Des/fiando as teias da paixão. Porto Alegre: EDIPUCRS, 2001, p.43). ${ }^{28}$ LISPECTOR, Clarice. A hora da estrela. Rio de Janeiro: Rocco, 1998a, p.60-61. 
identidade. O proibido e o permitido ou a culpa e o sossego perdem as fronteiras na nordestina e os sentidos desses termos são transgredidos, infringidos e subvertidos para dar lugar a novas categorias e possibilidades. Uma mulher culpada e feliz, uma moça que sonhava com sexo parecendo assexuada, uma nordestina que rezava sem outro destinatário que sua própria intranquilidade. Assim, Rodrigo, uma vez mais alerta sobre a enorme complexidade da existência de sua nordestina, de sua moça que longe está de ser essa incompetente para a vida, que não se refletia no espelho ou que sendo demasiado jovem já estava enferrujada. Macabéa vivia de menos, sim, mas ela era subterrânea e havia uma grande vitalidade soterrada nesse semblante pálido de fantasma suave:

\begin{abstract}
Quando dormia quase que sonhava que a tia lhe batia na cabeça. Ou sonhava estranhamente em sexo, ela que de aparência era assexuada. Quando acordava se sentia culpada sem saber por quê, talvez porque o que é bom devia ser proibido. Culpada e contente. Por via das dúvidas se sentia de propósito culpada e rezava mecanicamente três ave-marias, amém, amém, amém. Rezava mas sem Deus, ela não sabia quem era Ele e portanto Ele não existia ${ }^{29}$.
\end{abstract}

Também neste trecho, observa-se que o narrador aponta tanto essa sensualidade escondida da nordestina como a sua necessidade de resisti-la. Luta que além da vigília, chega até os sonhos da Macabéa. E essa resistência, esse conflito que a moça mantém contra si mesma está ligado a um conceito central da psicanálise que é definido como repressão, termo que pode ser entendido, segundo Laplanche e Pontalis ${ }^{30}$, como uma operação pela qual o sujeito rejeita ou mantém no inconsciente representações como pensamentos, imagens ou lembranças que estão ligadas a uma carga energética, a pulsão ${ }^{31}$, que faz tender o organismo à procura de um fim. Segundo os autores citados, a repressão se produz quando uma pulsão (que pode procurar por si prazer) pode ocasionar o perigo de sentir desprazer por outras exigências.

E nesta definição de repressão entra na cena o termo que se erige como essencial na prática psicanalítica: o inconsciente. A respeito, Laplanche e Pontalis referem que: "Si se

\footnotetext{
${ }^{29}$ LISPECTOR, Clarice. A hora da estrela. Rio de Janeiro: Rocco, 1998a, p.34.

30 LAPLANCHE, Jean; PONTALIS, Jean-Bertrand. Diccionario de Psicoanálisis. Buenos Aires: Paidós, 2001, p.375.

31 A pulsão pode ser entendida como um processo dinâmico consistente em um empurrar que faz com que o organismo persiga um objetivo. Na acepção freudiana, a pulsão possui sua fonte numa excitação corporal, sua finalidade é suprimir esse estado de tensão que reside na fonte pulsional e pelo objeto (objeto em si ou pessoa, real ou imaginário) alcança seu fim (LAPLANCHE, Jean; PONTALIS, Jean-Bertrand. Diccionario de Psicoanálisis. Buenos Aires: Paidós, 2001, p.324).
} 
hubiera de resumir en una palabra el descubrimiento freudiano, esta sería indiscutiblemente el término “inconsciente" ${ }^{\prime 32}$.

Para uma clara definição do termo em questão, citam-se as palavras de Speyer que refere que existe um sistema psíquico inacessível ao consciente que é chamado de inconsciente ou sistema primário (com um modo de funcionar que corresponde a uma mentalidade bastante primitiva) onde não existem o conceito de negação ou contradição, a noção de tempo, a verificação ou discernimento da realidade nem certos requisitos necessários para raciocinar com o realismo, lógica e coerência necessárias ${ }^{33}$.

Mas além de repressão e inconsciente, as referências do narrador clariceano introduzem um outro elemento muito caro ao pai da psicanálise: os sonhos.

A matéria onírica é apresentada por Rodrigo como um fato cercado pela raridade, pela surpresa, pois Macabéa "sonhava estranhamente em sexo, ela que de aparência era assexuada”. Mas o caráter insólito do sonhado por Macabéa não deve admirar pois, como Freud explica sobre este particular, para interpretar os sonhos deve-se supor que aquilo que é lembrado pelo sonhador quando acorda não é o processo onírico efetivo e real (o conteúdo manifesto), mas uma fachada detrás da qual o sonho está oculto (o pensamento onírico latente) ${ }^{34}$. Para entender o sonho, deve-se chegar a esse pensamento onírico latente utilizando-se esse estranho e desfigurado ${ }^{35}$ conteúdo manifesto. A respeito, Freud esclarece ainda mais dizendo que:

32 LAPLANCHE, Jean; PONTALIS, Jean-Bertrand. Diccionario de Psicoanálisis. Buenos Aires: Paidós, 2001, p.193.

33 SPEYER, W. Jonas. Freud o desconhecido. Assis (SP): FFCL - Faculdade de Filosófica, Ciências e Letras, 1963, p.27. Outros dos sistemas existem paralelamente ao inconsciente, o sistema secundário ou pré-consciente que possui as características que faltam no inconsciente e o sistema consciente onde tais características se cristalizam no pensamento superior, ou seja, no raciocínio lógico, coerente e realista (SPEYER, W. Jonas. Frend o desconhecido. Assis (SP): FFCL - Faculdade de Filosófica, Ciências e Letras, 1963, p.27).

${ }^{34}$ FREUD, Sigmund. Obras Completas. v. XXIII. Buenos Aires: Amorrortu, 1997, p.163.

35 Freud refere a respeito que o estudo do trabalho do sonho ensina "como un material inconsciente, un material originario y reprimido, se impone al yo, deviene preconciente y en virtud de la revuelta del yo experimenta las alteraciones que conocemos como desfiguración onírica" (FREUD, Sigmund. Obras Completas.. v. XXIII. Buenos Aires: Amorrortu, 1997, p.163-164). Em "Algunas observaciones sobre el concepto de lo inconsciente en el psicoanálisis" (1912) Freud explica a formação onírica com um exemplo esclarecedor: "Un caso típico de formación onírica puede ser descrito del modo siguiente: la actividad anímica diurna ha despertado una serie de ideas que ha conservado algo de su eficacia, escapando así a la general anulación del interés que trae consigo el reposo y constituye la preparación espiritual del dormir. Esta serie de ideas consigue, durante la noche, ponerse en conexión con uno de los deseos inconscientes que desde la infancia del sujeto se hallan siempre presentes en su vida anímica, aunque por lo regular reprimidos y excluidos de la existencia consciente. Por medio de la energía que les presta este apoyo inconsciente recobran su eficacia las ideas residuales de la actividad diurna y quedan capacitadas para surgir en la consciencia bajo la forma de un sueño" (FREUD, Sigmund. "Algunas observaciones sobre el concepto de lo inconsciente en el psicoanálisis" (1912). In: Freud Total 1.0: Sigmund Freud. Obras completas. Biblioteca eLe. Nueva Hélade, 1995). Também Gay define o sonho manifesto e o pensamentos latentes do sonho dizendo que: "O primeiro corresponde ao que o indivíduo sonha e lembra de modo mais ou menos impreciso ao acordar; os outros, os pensamentos latentes do sonho, estão ocultos e normalmente só apareceram, se tanto, densamente velados, exigindo decodificação" (GAY, Peter. Freud: uma vida para o nosso tempo. São Paulo: Companhia das Letras, 1989, p.113). 
[...] os sonhos dos adultos via de regra têm um conteúdo ininteligível, sem nenhuma semelhança com a satisfação de desejos. Resposta: estes sonhos estão distorcidos, o processo psíquico correspondente teria originariamente uma expressão verbal muito diversa. O conteúdo manifesto do sonho, recordado vagamente de manhã e que, não obstante a espontaneidade aparente, se exprime em palavras com esforço, deve ser diferenciado dos pensamentos latentes do sonho que se têm de admitir como existentes no inconsciente ${ }^{36}$.

Por isso, quando Macabéa sonha com sexo, pode-se inferir que estes conteúdos oníricos estão exteriorizando um erotismo reprimido que é mutilado sistematicamente pelo rito da prece sistemática, do protocolo do alívio, da etiqueta da tranquilidade e do soterramento dos desejos. Mas a aparência assexuada da nordestina é só fachada, um aspecto frágil que transita a vigília da moça virgem da história clariceana. Os sonhos da Macabéa dizem muito dela. Entender os sonhos da jovem é entendê-la. Sobre este particular, Freud alerta dizendo que: “A interpretação de sonhos é na realidade a estrada real para o conhecimento do inconsciente, a base mais segura da psicanálise". E é por isso que não deve assombrar que Macabéa sonhe com sexo, com desejos reprimidos que causam o estranhamento do narrador clariceano quando refere sua assexuada personagem ${ }^{37}$.

Embora Rodrigo só informe que a jovem nordestina sonha com sexo sem detalhar o conteúdo da atividade onírica, pode-se igualmente assinalar que, segundo os pensamentos freudianos, Macabéa nos seus sonhos transgride as fortes barreiras que as resistências da vigília impõem a seus desejos reprimidos. Neste sentido, Freud explica que:

O conteúdo manifesto do sonho é o substituto deformado para os pensamentos inconscientes do sonho. Esta deformação é obra das forças defensivas do ego, isto é, das resistências que na vigília impedem, de modo geral, a passagem para a consciência, dos desejos reprimidos do inconsciente; enfraquecidas durante o sono, estas resistências ainda são suficientemente fortes para só os tolerar

\footnotetext{
${ }^{36}$ FREUD, Sigmund. Cinco licões de psicanálise. A bistória do movimento psicanalítico. O futuro de uma ilusão. O malestar na civiliząąão. Esboço de psicanálise. São Paulo: Abril S/A Cultural e Industrial, 1978, p.21.

${ }^{37}$ Ibidem, p.20. Essa aparente falta de correlato entre a vigilia e o sonho também pode ser rastreada em outros textos clariceanos como em "A partida do trem". Ali se observam as diferenças entre a Ângela do sonho, a vagabunda, e a da vigília, a letrada: "Ângela sonhava com a fazenda: lá se ouviam gritos, latidos e uivos de noite. [...] eu sou uma vaca, sou uma cavala livre e que pateia no chão, sou mulher da rua, sou vagabunda- e não uma 'letrada"' (LISPECTOR, Clarice. Onde estivestes de noite. Rio de Janeiro: Rocco, 1999b, p.28). Já em outros textos como "Duas histórias a meu modo", além de serem referidos ambos campos, o do sonho e o da vigília, assinala-se como pouco saudável a transgressão da suas fronteiras: "De sonho dormido passou a sonho acordado, o que já é doença" (LISPECTOR, Clarice. Felicidade clandestina. Rio de Janeiro: Rocco, 1998c, p.156).
} 
disfarçados. Quem sonha, portanto, reconhece tão mal o sentido de seus sonhos, como o histérico as correlações e a significação de seus sintomas ${ }^{38}$.

A luta da Macabéa está dada nessa relação de resistências e desejos reprimidos que originam culpas e que na nordestina apareciam de maneira singular. Macabéa se sentia culpada quando acordava, mas era uma culpa misturada com felicidade que fazia pensar em que "o que é bom devia ser proibido" e por isso rezava. Essa sensação prazerosa e proibida deveu resultar difícil de processar para a moça e, por isso, entender ou experimentar a própria sexualidade quiçá foi uma necessidade, assim como a sua religiosidade, ignorada ou banida.

Mas a conduta da Macabéa não deve chamar muito a atenção. Segundo Freud, no campo da sexualidade o homem não é sincero e exibe claras dificuldades para demonstrar o que deseja: "Em matéria sexual os homens são em geral insinceros. Não expõem a sua sexualidade francamente; saem recobertos de espesso manto, tecido de mentiras, para se resguardarem, como se reinasse um temporal terrível no mundo da sexualidade" ${ }^{\text {39. }}$. Mentiras que se sustentam na grande pressão social que a pessoa sofre quando deseja manifestar sua faceta sensual e que concluem na repressão de seus impulsos mais naturais. Sobre este particular, Freud explica que:

Já antes da puberdade, sob o influxo de educação, certos impulsos são submetidos a repressões extremamente enérgicas, ao mesmo passo que surgem forças mentais - o pejo, a repugnância, a moral - que como sentinelas mantêm as aludidas repressões. Chegando na puberdade a maré das necessidades sexuais, encontra nas mencionadas reações psíquicas diques de resistência que lhe conduzem a corrente pelos caminhos chamados normais e lhe impedem reviver os impulsos reprimidos ${ }^{40}$.

E é justamente esse impulso que quer aparecer na sua máxima expressão o que Macabéa conhece e que Rodrigo expõe quando narra que sua personagem distinguia claramente das outras necessidades:

Ela sabia o que era o desejo - embora não soubesse que sabia. Era assim: ficava faminta mas não de comida, era um gosto meio doloroso que subia do baixoventre e arrepiava o bico dos seios e os braços vazios sem abraço. Tornava-se toda dramática e viver doía. Ficava então meio nervosa e Glória lhe dava água com açúcar ${ }^{41}$.

38 FREUD, Sigmund. Cinco lições de psicanálise. A história do movimento psicanalítico. O futuro de uma ilusão. O malestar na civilização. Esboço de psicanálise. São Paulo: Abril S/A Cultural e Industrial, 1978, p.21.

39 Ibidem, p.25.

40 Ibidem, p.28.

${ }^{41}$ LISPECTOR, Clarice. A hora da estrela. Rio de Janeiro: Rocco, 1998a, p.45. 
Água com açúcar neste caso, rezar mecanicamente em outros, são condutas que, de certa forma, procuram anestesiar o desejo da Macabéa, um desejo que aparece com uma forma tal que deve ser reprimido, pois essa fome da nordestina era quase um pecado que atentava à moralidade, aos bons costumes de uma sociedade assexuada na sua cara pública. A respeito, Freud refere em sua segunda lição sobre a psicanálise que estes desejos violentos contrastam com os outros desejos do indivíduo e são incompatíveis com a moralidade ${ }^{42}$ e a estética das próprias personalidades ${ }^{43}$. E esse choque de sentimentos gera conflitos e lutas internas que acabam na repressão do desejo ${ }^{44}$ ou da ideia que aparecia na consciência vinculada a tal desejo inconciliável, sendo, finalmente, a incompatibilidade de tal ideia e o ego da pessoa o motivo da repressão. As forças repressivas, acrescenta Freud, cumprem tal função, pois aceitar um impulso desejoso inconciliável ou a permanência de uma situação conflitiva ocasionaria um grande desprazer. Por tal razão o ato repressor que tenta evitar o desprazer, de certo modo, torna-se uma ferramenta de "proteção" da dimensão psíquica, defesa que não resguarda completamente o aparelho psíquico do desejo reprimido. Sobre este particular, Freud explica que:

[...] o impulso desejoso continua a existir no inconsciente à espreita de oportunidade para se revelar, concebe a formação de um substituto do reprimido, disfarçado e irreconhecível, para lançar à consciência, substituto ao

\footnotetext{
42 Gay explica que os livros de etiqueta, a proibição da nudez nas praias, a prescrição de obediência aos superiores, por exemplo, são formas que a cultura utiliza para canalizar, limitar e frustrar os desejos das pessoas. Mas a pulsão sexual (e o restante das pulsões primitivas) continua resistindo as proibições restritivas para alcançar uma gratificação. Segundo o autor o próprio engano e a hipocrisia "são os companheiros conscientes da repressão, negando necessidades apaixonadas em nome da concórdia familiar, da harmonia social ou da simples respeitabilidade. Negam essas necessidades, mas não podem destruí-las" (GAY, Peter. Freud: uma vida para o nosso tempo. São Paulo: Companhia das Letras, 1989, p.131). Essa impossibilidade de apagar ou negar o desejo quiçá explique as afirmações de Rodrigo quando diz que o sexo da Macabéa "era a única marca veemente de sua existência. Ela nada pedia mas seu sexo exigia, como um nascido girassol num túmulo" (LISPECTOR, Clarice. A hora da estrela. Rio de Janeiro: Rocco, 1998a, p.70). O sexo da Macabéa, a flor no túmulo, é, talvez, o grande manancial que dá vida à moça enferrujada, amarelada, e quase morta que o narrador clariceano descreve, por momentos, com enorme compaixão.

${ }^{43}$ FREUD, Sigmund. Cinco lições de psicanálise. A história do movimento psicanalítico. O futuro de uma ilusão. O malestar na civilização. Esboço de psicanálise. São Paulo: Abril S/A Cultural e Industrial, 1978, p.13.

${ }^{44}$ A respeito, Gay adverte que os desejos geram conflitos no inconsciente porque são contrário às normativas das instituições culturais e embora possam reprimidos, eles continuam ativos, pois, como afirmava Freud, eles não podem ser destruídos (GAY, Peter. Freud: uma vida para o nosso tempo. São Paulo: Companhia das Letras, 1989, p.133). Também Gay assinala que: "No inconsciente, nada pode ser terminado, nada é passado ou esquecido' Mas depois de algum tempo, esses desejos, por assim dizer, refinam-se. O que Freud chamava de 'processo primário', o conjunto das energias primitivas indomadas desde o início instalado na mente, está inteiramente sob o domínio do princípio do prazer: ele quer satisfação, imprudentemente, de modo totalmente brutal, sem paciência para a reflexão ou o adiamento. Mas, com os anos de desenvolvimento, a mente consegue sobrepor um 'processo secundário' que leva em conta a realidade; ele regula $\mathrm{O}$ funcionamento mental de modo menos apaixonado e mais eficiente, introduzindo o pensamento, o cálculo, a capacidade de adiar as satisfações para gozá-las posteriormente" (GAY, Peter. Freud: uma vida para o nosso tempo. São Paulo: Companhia das Letras, 1989, p.133-134).
} 
qual logo se liga a mesma sensação de desprazer que se julgava evitada pela repressão ${ }^{45}$.

Que o desejo não desaparece, pode ser percebido abertamente na moça virgem ${ }^{46}$ que não consegue erradicar esse gosto meio doloroso que subia do baixo-ventre e arrepiava o bico dos seios embora suas condutas pareçam traduzir um enorme esforço para erradicar ou evitar situações que envolvam traços de erotismo ou sensualidade. Condutas repressoras que se observam, por exemplo, quando Macabéa, enxugando o rosto com a saia logo de um tombo, diz a seu efêmero namorado Olímpico que não olhe porque é proibido levantar a saia ou quando declara que escutou dizer que no médico se tira a roupa, mas que ela não tira coisa nenbuma.

A moça que não nunca se viu nua, a que não levantava sua saia, a que rezava para mitigar seus desejos é a mesma moça que se sentia culpada, mas feliz. Macabéa podia perder todo traço humano e ser o fantasma suave de uma menina sem bonecas que beijava as paredes, uma jovem enferrujada de corpo cariado num escritório carioca, ou uma rapariga que só conheceu a esperança momentos antes de ser atropelada, mas sua existência plena como ser humano estava dada pelo grande apetite que carregava. Apetite que o narrador clariceano expõe com singular clareza quando refere que esqueceu "de dizer que às vezes a datilógrafa tinha enjôo para comer. Isso vinha desde pequena quando soubera que havia comido gato frito. Assustou-se para sempre. Perdeu o apetite, só tinha a grande fome" 47 .

A grande fome que longe de ser um sofrimento em Macabéa era uma forma de sentir sua existência com aptidão, uma maneira de deixar de ser a incompetente para a vida como era definida por Rodrigo. O sexo ou a sexualidade ${ }^{48}$ eram elementos que, longe de uma possível ideia de procriação incutida por uma tia religiosa que não se casara por nojo, vieram a despertar em Macabéa profundas e intrincadas emoções que se fundiram como

\footnotetext{
45 FREUD, Sigmund. Cinco lições de psicanálise. A história do movimento psicanalítico. O futuro de uma ilusão. O malestar na civilização. Esboço de psicanálise. São Paulo: Abril S/A Cultural e Industrial, 1978, p.13.

46 Virgindade que é vista no texto como um fato prejudicial para esse enorme caudal de desejos sexuais que Macabéa carrega. Nesse sentido, Madame Carlota alerta sobre os benefícios decorrentes da aproximação aos homens: "Você sabe, meu amor, que cheiro de homem é bom? Faz bem à saúde. Você já sentiu cheiro de homem? - Não senhora" (LISPECTOR, Clarice. A hora da estrela. Rio de Janeiro: Rocco, 1998a, p.75).

${ }^{47}$ LISPECTOR, Clarice. A hora da estrela. Rio de Janeiro: Rocco, 1998a, p.39.

48 Parece pertinente referir que os termos sexo e sexualidade tomam em Freud uma conotação singular. Sobre este ponto, Speyer explica que os dois termos, no latim e nos idiomas que os assimilam, possuem significados inequívocos: "O sexo é o conjunto dos caracteres que distinguem o homem da mulher, o macho da fêmea; sexualidade é, por tanto, a qualidade de ter sexo, e - na psicologia - o conjunto dos instintos e dos impulsos ligados ao sexo". Mas para Freud, o termo sexualidade alcança um significado singular, a sexualidade na óptica freudiana se define, em parte, como a totalidade das tendências para buscar-se prazer nos órgãos do corpo, noção que vai além, no olhar do psicanalista, da exclusividade dos órgãos genitais (SPEYER, W. Jonas. Freud o desconhecido. Assis (SP): FFCL - Faculdade de Filosófica, Ciências e Letras, 1963, p.26).
} 
uma existência que se estremecia pelo ímpeto do desejo ${ }^{49}$. Macabéa não era uma datilógrafa apática com um rosto de tola que pedia tapas. Macabéa foi a garota que nos últimos instantes de vida teve uma felicidade úmida e suprema, quando nascera para o abraço da morte. E a contradição de Rodrigo se desvanece na agonia da Macabéa. A moça que para o narrador parecia morta em vida, era a mesma que brilhava com luz própria por seu desejo, como uma estrela, e na hora dessa estrela, faz-se patente essa particularidade. Quando Macabéa agoniza, começa a entregar o único que lhe dava vida na narração, seu desejo: "Iria ela dar adeus a si mesma? Acho que ela não vai morrer porque tem tanta vontade de viver. E havia certa sensualidade no modo como se encolhera. Ou é porque a pré-morte se parece com a intensa ânsia sensual? É que o rosto dela lembrava um esgar de desejo" ${ }^{\text {" }}$.

Macabéa, a garota desluzida, a nordestina apagada, a jovem desbotada que Rodrigo apresenta na sua narração é uma estrela que só cintila quando deseja, um astro que unicamente resplandece quando se excita, um temeroso satélite que reverbera apenas quando se inflama. Em A Hora da Estrela, Macabéa é sopa fria, ferrugem e desânimo, mas também é palavra que resplandece quando o narrador clariceano refere o sexo coberto de grossos e abundantes pelos negros da sua personagem. E essa grossura, essa abundância é insuficiente para conformar uma trincheira que soterre a única marca veemente da existência da nordestina clariceana em sua vida fosca e sombria de papéis manchados e erros datilográficos.

\section{Considerações finais}

Algumas noções básicas sobre a teoria psicanalítica surgidas das cinco conferências ou lições de Freud na Clark University de Worcester, Massachusetts, em 1909 e o texto de Clarice Linspector $A$ bora da estrela de 1977 tentaram ser aproximados nas páginas deste trabalho.

Sigmund Freud apresenta, nas suas conferências, entre outras temáticas, noções básicas sobre interpretação de sonhos, repressão e sexualidade. E são estes tópicos os que permitem familiarizar alguns princípios essenciais da psicanálise com a personagem principal do texto estudado, Macabéa. É a jovem protagonista nordestina que chega através do narrador clariceano, Rodrigo S.M., a que permite o encontro entre literatura e

\footnotetext{
${ }^{49}$ Nesse sentido, Freud explica que os complexos instintos sexuais são independentes da função procriadora, embora posteriormente se coloquem ao serviço da mesma, e servem para dar oportunidades a diferentes classes de sensações agradáveis que o ser humano, por analogias e conexões, entende como prazer sexual (FREUD, Sigmund. Cinco liçös de psicanálise. A bistória do movimento psicanalitico. O futuro de uma ilusão. O mal-estar na civilização. Esboço de psicanálise. São Paulo: Abril S/A Cultural e Industrial, 1978, p.13).

${ }^{50}$ LISPECTOR, Clarice. A hora da estrela. Rio de Janeiro: Rocco, 1998a, p.84.
} 
psicanálise. Um encontro que, atenuando os limites de cada disciplina, cria um espaço comum onde convivem o método científico e a ficção.

Clarice, com seu hesitante Rodrigo, permite a confluência harmônica dos fundamentos da psicanálise no relato literário e uma espécie de pacto implícito entre a ciência e a imaginação criadora. Neste acordo, o componente conciliador, a cláusula que amanceba os extremos está escrita por Macabéa, moça decadente, quase ruína, que porta em si, oculta, solapada, as forças vitais que ressuscitam sua existência desvanecida: o desejo, o erotismo, a sensualidade.

A psicanálise alerta sobre a aparição de desejos violentos que contrastam com as condutas morais e o recato das pessoas e Macabéa favorece a força de tal afirmação. Quando a jovem nordestina deseja, quando se faz presente a grande fome, a indiferença vira frenesi, a apatia, estímulo e o desinteresse, agitação. Macabéa vive plenamente nessas ocasiões e até a mesma agonia da morte não é empecilho para esta força irresistível, para este ímpeto descontrolado. $\mathrm{Na}$ passagem da vida à morte o prazer acompanha Macabéa e facilita a transformação da virgem em mulher. Neste clímax narrativo, neste ápice clariceano, A hora da estrela e as "Cinco lições de Psicanálise" se associam ainda mais para permitir uma espécie de interpretação analítica do texto literário, ou melhor, para permitir uma viagem que, partindo da psicanálise, tenta chegar à literatura. Nesta viagem, uma jovem mulher do nordeste abre uma apertada brecha para decifrar uma fração do universo clariceano através de conceitos freudianos e, de certa forma, para interpretar exiguamente a descomunal complexidade da personalidade humana. 


\section{REFERÊNCIAS BIBLIOGRÁFICAS}

BARBOSA, Maria José S. Clarice Lispector. Des/fiando as teias da paixão. Porto Alegre: EDIPUCRS, 2001.

BELLEMIN-NOËL, Jean. Psicanálise e literatura. São Paulo: Cultrix, 1978.

FREUD, Sigmund. "Algunas observaciones sobre el concepto de lo inconsciente en el psicoanálisis" (1912). In: Freud Total 1.0: Sigmund Freud. Obras completas. Biblioteca eLe (editorial del libro electrónico). Nueva Hélade, 1995.

. Cinco lições de psicanálise. A história do movimento psicanalítico. O futuro de uma ilusão. O mal-estar na civilização. Esboço de psicanálise. São Paulo: Abril S/A Cultural e Industrial, 1978.

. Obras Completas. v. V. Buenos Aires: Amorrortu, 2000.

v. IX. Buenos Aires: Amorrortu, 1996.

. v. XI. Buenos Aires: Amorrortu, 2003.

. v. XXIII. Buenos Aires: Amorrortu, 1997.

GAY, Peter. Frend: uma vida para o nosso tempo. São Paulo: Companhia das Letras, 1989.

GOTLIB, Nadia B. Clarice: Uma vida que se conta. São Paulo: Ática, 1995.

LAPLANCHE, Jean; PONTALIS, Jean-Bertrand. Diccionario de Psicoanálisis. Buenos Aires: Paidós, 2001.

LISPECTOR, Clarice. A bora da estrela. Rio de Janeiro: Rocco, 1998a.

. A via crucis do corpo. Rio de Janeiro: Rocco, 1998b.

. A legião estrangeira. Rio de Janeiro: Rocco, 1999a.

. Felicidade clandestina. Rio de Janeiro: Rocco, 1998c.

. Laços de familia. Rio de Janeiro: Rocco, 2009.

. Onde estivestes de noite. Rio de Janeiro: Rocco, 1999b.

MORITZ-KON, Noemí. "De Poe a Freud - O gato preto". In: BARTUCCI, Giovanna (Org.). Psicanálise, literatura e estéticas de subjetivação. Rio de Janeiro: Imago, 2001.

SPEYER, W. Jonas. Frend o desconhecido. Assis (SP): FFCL - Faculdade de Filosófica, Ciências e Letras, 1963.

WILLEMART, Philippe. Além da psicanálise: a literatura e as artes. São Paulo: Nova Alexandria: FAPESP, 1995.

WINTER, Lígia Maria; MOTTA, Sérgio Vicente. “O entrecruzamento erótico, pictórico e musical em A hora da estrela”. In: Estudos Lingüisticos, v. XXXV, p.1123-1129, 2006. 